\title{
SUBLRISHING Administration and Law
}

Journal homepage: http://real.spcrd.org ISSN (Print): 2708-1788

\section{Sociocultural and Religious Prospects of the Issue of Gender Disparity: Pakistan Perspective}

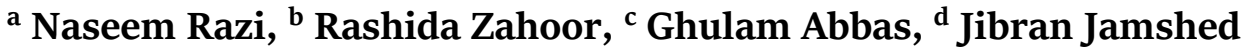

${ }^{a}$ Associate Professor of Law, Department of Law, Faculty of Shari'ah and Law, International Islamic University, Islamabad, Pakistan.

Email: naseem.razi@iiu.edu.pk

${ }^{\mathrm{b}}$ Assistant Professor, Department of Law, University of Sahiwal, Sahiwal, Punjab, Pakistan.

Email: rashidazahoor@uosahiwal.edu.pk

${ }^{c}$ Assistant Professor, Department of Law, Bahria University, Islamabad, Pakistan.

Email: a.ghazi22@gmail.com

${ }^{\mathrm{d}}$ Assistant Professor, Department of Law, Islamia University of Bahawalpur, Bahawalpur, Pakistan.

Email: Jibran.jamshed@iub.edu.pk

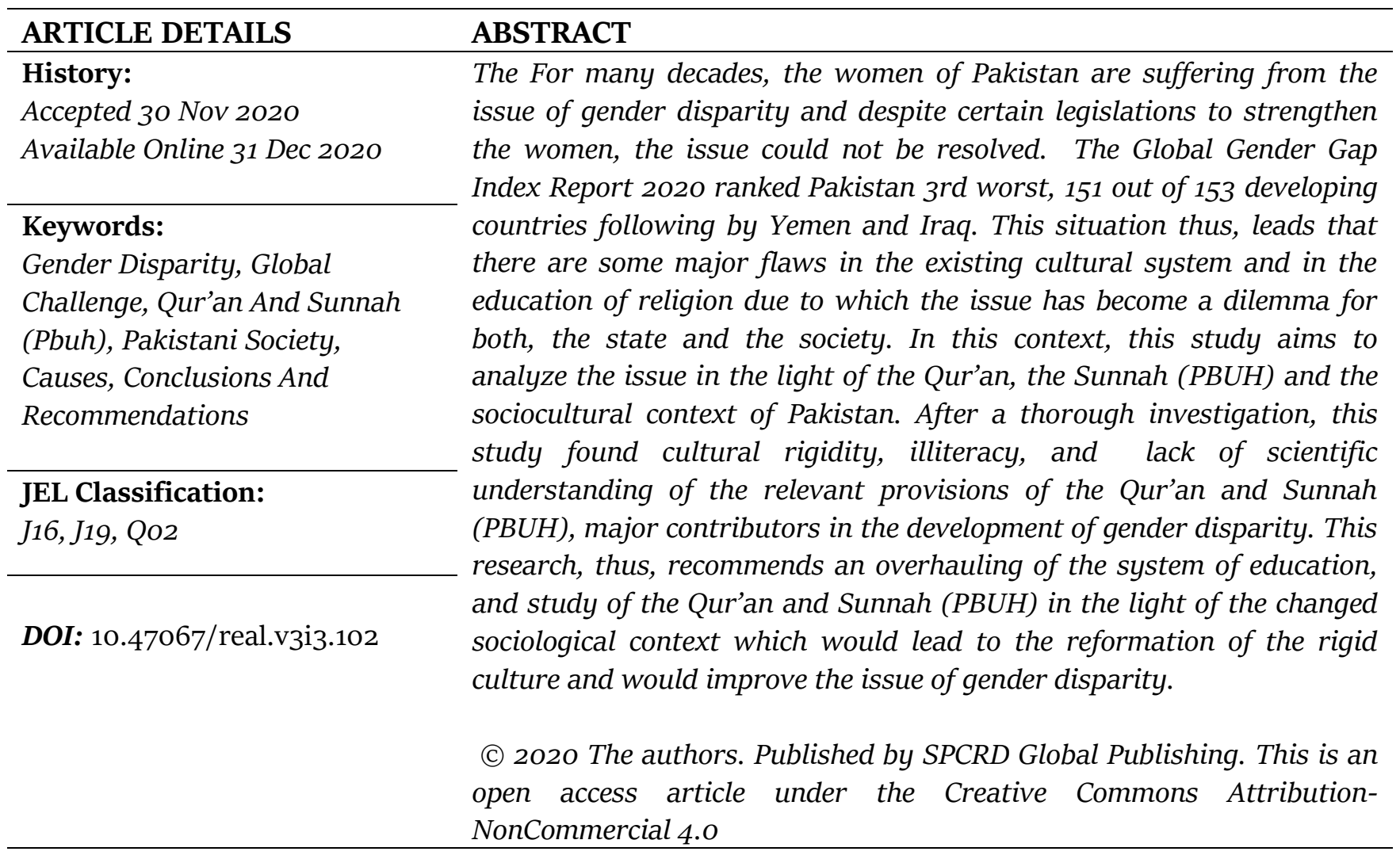

Corresponding author's email address: Email: Jibran.jamshed@iub.edu.pk

\section{Introduction}

The term gender refers to the sort of different characteristics between male and female on the basis of their physical, biological, mental and behavioral attributes ( Lessard, and Heston, 2017). The unavoidable complexity of the social world has led many issues for the people created on the basis of 
their gender like issue of lack of capacity, ability, cooperation, opportunities and interaction between two most important genders, i.e., men and women (Connell., 1987). Further, cultural context, ethical values, customary practices, and religious norms affect the lives of the people being male or female (Kirk and Okazawa-Rey's, 2004). As Gerstel, (2003) pointed out that the social structure, long-lasting social relationships, practices and institutions have great impact on the lives of the people and that can be difficult to see in our daily lives and which led in gender discrimination". The issue of gender discrimination caused to create many problems for women like suppression, violence, exploitation, forced and bonded labour, lack of equal opportunity and criticism, etc. (Duggan, 2003).

Social activists started observing oppressed people, including women, workers, immigrants, children and their problems from the actual day-to-day experiences of groups of people who have traditionally been excluded from the production of academic knowledge and economic growth (Pierrette, 2001). All this resulted in the philosophical studies of women as an independent gender and evolved feminist theories in the late 1960s, which later on, fueled the increase in women's participation in the labour force and economic development (Gerstel, 2003). In 1970s, certain feminist movements appeared such as socialist feminist theory, radical feminist theory, black feminist theory, trans-feminist theory and inter-sectional feminist theory, etc., with an argument that people with less power and resources often experience the effects of oppressive social systems in ways that members of dominant groups do not, so, the social system should empower women in every field of life (Jepperson, 1991).

In response to women's protest against injustice, gender discrimination, lack of opportunities in getting education and participation in the economic development, the Universities of USA, established the 'Women's and Ethnic Studies departments' in the 1970s, across the country (KANG, DONOVAN, and HESTON, 2017). The concept of gender equality emerged which leads that both men and women have equal rights, and duties and opportunities to grow and to develop being human (DAVIE, 2015). The link between the socioeconomic development and the gender equality was realized by acknowledging some unique attributes of the women such as women were found to have more concern for the development of the family and society (Gumplowicz, 1990; Buenfil, 2011). Gender disparity was declared a major contributor in the violence against women, harassment of women, exploitation, illiteracy, poverty, moral decay and destruction of the family life (Gumplowicz, 1990).

The feminist movement not only recognize the inseparable connection between the notion of gender equality, not only for women, but also for men and the oppressed people. In this way, the feminism appeared not as a single school of thought, but comprehends various theories and analytical perceptions (Thomas, 1998).

This research aims to evaluate the issue of gender disparity in Pakistan in its prevailing sociocultural and religious context. In the light of the current gender profile of the country, this research seeks to explore, identify and categorize some causes behind the issue. It also aims to investigate the issue in the light of the relevant verses of the Qur'an and Sunnah (pbuh) to point out that Islam as religion discourage gender disparity and promote gender equality.

These are following Research Questions:

- Whether or not the gender disparity a global issue?

- How and in what manners, Qur'an and Sunnah (pbuh) establish gender equality and condemn gender disparity?

- What are major causes behind the issue of gender disparity in Pakistan? 
- What Policy measures should be adopted to reduce gender disparity and to achieve gender equality?

This study is restricted to focus on evaluating the issue in four areas targeted by the "Global Gender Gap Index 2002", like equality between men and women in getting education, equality in access to health and survival, equality in economic opportunity and equality in political liberty.

This study is divided into three parts: The first part evaluates the issue of gender disparity in global context. The second part discusses the issue in its religious context with reference to Islam. The third part discusses the issue in the sociocultural and religious context of Pakistani society. In the end some conclusions are drawn and some recommendations are recommended to overcome the issue of gender disparity and to promote gender equality in Pakistan.

\section{Literature Review}

KANG, LESSARD, AND HESTON (2017) in their book “ Introduction to Women, Gender, Sexuality Studies," Discussed the issue of gender disparity in critical manners by highlighting the issues faced by the women because of discrimination and has declared it a global issue to be resolved by the stakeholders.

Kimmel (2007), discussed the issue with reference to socialization that society itself can improve the situation regarding gender discrimination and that different social institutions such as Primarily, the family, schools, media, peer groups , religious institutions, can play as primary agents of gender equality and social stability while Debois, and Dumenil (2005) in their writing, "Through Women's Eyes: An American History With Documents," discussed the issues of women during the $1920 \mathrm{~s}$ by pointing out that "how feminist activists channeled their energy into institutionalized legal and political channels for effecting changes in labor laws and attacking discrimination against women in the workplace".

Davis (1983) in his book “ Women, Race, and Class," pointed out that the due to the feminist movement fueled the increase in women's labor force participation during the 196os and 1970s. Kirk, and Okazawa (2004), discussed the issue and highlighted that the issue of gender disparity is rooted in the cultural backwardness and illiteracy and that it causes violence and exploitation of women in every aspect of their lives."

Mink, (2004), in his writing, "Violating Women: Rights Abuses in the Welfare Police State", pointed out that gender disparity could not be reduced and declared it as an abuse of the rights of women. Greenberg, J., (2002) pointed out in his article "Definitional Dilemmas: Male or Female? Black or White?," the issues arising out of gender disparity.

Economist Nancy Folbre (2001) has argued that there is a lot of work which women have traditionally done in the home, raising children and caring for sick and dying relatives, usually for free as 'care work.' However, much of the time, this care work is taken undervalued both because women are more likely to do it and because it is considered to be natural for women to know how to care.”

Duggan, (2003) in his writing, “The Twilight of Equality? Neoliberalism, Cultural Politics, and the Attack on Democracy," pointed out that in "Us and across the globe more and more women live in underprivileged condition, despite the fact that many are working. Women's unequal access to 
resources and the disproportionate responsibility for unpaid work placed on them set up a situation in which women can either be supported by a breadwinner or struggle to make ends meet.”

Morgan and Robin (1996) discussed the feminist movement and its role in the development of the notion of gender equality. Kimberlé Crenshaw (1991), wrote that "the concept of intersectionality identifies a mode of analysis and that the people experience these multiple aspects of identity in their lives. The author, further, argues that within inter-sectional frameworks, race, class, gender, sexuality, age, ability, and other aspects of identity are considered mutually constitutive."

Scott (1991), discussed the issue of gender disparity with reference to a common misconception among the people that knowledge is produced by rational and impartial male scientists and observed that such misconception often obscures the ways that scientists create knowledge through gendered, raced, classed, and sexualized cultural perspectives.

Moreover, to collect updated data and statistics, the authors have gone through many reports such as 'United Nations, Gender Mainstreaming July 2001,' 'UN Women Office Report on Progress of the World's Women 20', and reports of Geos and NGOs etc.

To explore the issue from a religious perspective, the authors consulted the relevant verses of the Qur'an, and their tafasir, books of ahadith of the Prophet (pbuh) like Sahih al-Bukhari, Sahih alMuslim, Sunnan Abi Dawud and Sunnan Ibn Majah etc. The authors also have gone through the writings of historians such as Ibn Hashsham, (1990), Al-Tabari, (1998), Mubarakpuri (1995), and Siddiqi, (1998).

The authors also consulted the writings of contemporary Muslim jurists to analyze the issue in the light of the objectives of Islamic legal system, such as Rida, (1987) reinterpreted the relevant verses of the Qur'an in the light of the changed legal context and demands of the changed period in favor of

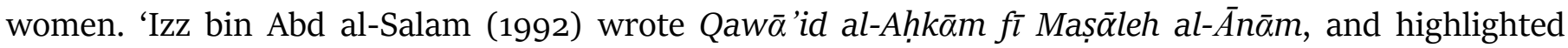
importance of maslahah/ public interest to resolve the issues of daily life. Yūsuf al-Qarḍ̄̄wī, (1985) also issued many fatawa in favor of women to reduce gender disparity. Tahir bin Ashur (2000) wrote about the importance of the objectives of revelation and opined that the social issues of the people should be resolved by way of ijtihad al-maqasidi/purposive interpretation.

\section{Research Methodology}

The method of data collection is based on the study of the primary and secondary sources such as encyclopedias, books, articles, survey and reports. To explore the religious aspect of the issue, this research has an extensive rely on the Qur'an and Sunnah (pbuh) and writings of Muslim interpreters, compilations of ahadith and writings of Muslim jurists and philosophers

\section{Discussion}

\subsection{Gender Disparity in Global Context}

In the mid of the $2 \mathrm{O}^{\text {th }}$ century, the modern world recognized that women constituent half of the total population of the world and that women can contribute positively in the socioeconomic and environmental development of the society, this led the UNO to motivate its member states to work for the betterment of women that women should be provided equal opportunities to men in every field of 
their lives (Winch, 2003; Buenfil, 2011). Consequently, in 1985, the UN declared the whole decade for Women: Equality Development and Peace”. Almost 157 states adopted 'the Nairobi Forward-looking Strategies for the Year 2000' which declared 'all issues to be women's issues (https://www.un.org/en/sections/issues-depth/gender-equality).

Later on in 1995 'gender mainstreaming' was established as a paramount global stratagem ender equality in the 'Beijing Platform for Action from the Fourth United Nations World Conference on Women in Beijing'. The United Nations expressed its concerns to protect the inherent human dignity of women and men as guaranteed by the UN Charter 1945 and for gender equality, the Universal Declaration of Human Rights 1948 (UDHR)", and other instruments like "the Convention on the Elimination of All Forms of Discrimination against Women 1979 (CEDAW)" and "the Convention on the Rights of the Child 1989 (CRC)", as well as "the Declaration on the Elimination of Violence against Women" and "the Declaration on the Right to Development", were adopted. It was declared that without considering the importance of women the targeted development of the world cannot be achieved. If women do not participate fully in the socio-economic development, the world will lose half of the potential of the society. The term gender disparity thus, defined as the meaning of a gap between male and female in any field of life (United Nations, Gender Mainstreaming, 2001).

The world declared the issue of gender disparity as a global threat, and a grave violence of the fundamental of rights of women. Any form of discrimination on the basis of gender has been declared a denial of dignity and self-respect of the women (UN Women Office, 2000).

To examine the issue on a regular basis, in 2006, the "World Economic Forum" established a system of tracking the issue of gender disparity “The Global Gender Gap Index". The Global Gender Gap Index is targeted to evaluate the status of equality between men and women in four fields like equality in getting education, equality in access to health and survival, equality in the economic opportunity and equality in political liberty.

It is, however, a matter of great concern that the issue of gender disparity could not be reduced and is going rise particularly, in the countries of rigid culture like Pakistan.

\subsection{Gender Disparity and Religious Projections}

Talking about the status of gender disparity, prior to Islam, gender disparity was a wellrecognized dogma and most of the nations of the world were victim of this dogma and did not have the concept of gender equality (Ibn Hashsham, 1990; Mubarakpuri, 1995; Siddiqi, 19998). Men as the leader and guardian of a society had to consider women as subservient to them and as their personal properties (Ayelet, 2001; Gutwie, 1962). Greek philosophers like Aristotle (322 BCE) recommended for women staying at home and learning household skills. Women were not allowed to go out of home for getting the knowledge and skills to participate in the development of the economy of the state (Betoncourt, and Lopez, 1993; Barker, 2011).

In the same manners, Arabs also considered women as their servants and a subject for sale and purchase. In addition to that, most of the men did not like to be fathers of daughters. Many of them were so cruel that if a baby girl was delivered at the home of anyone, he preferred to bury her alive than to bring her up. The newborn baby girl thus, granted the punishment of death as being womanly (Ibn Hashsham, 1978; Al-Tabari, 1988; Al-Razi, 1976; Rahman, 1988). 
Islam revealed in the early $7^{\text {th }}$ century, as the last religion dealt with the issues of human beings in every aspect of their lives. To eradicate corrupt socio-ethical and religious practice and to establish a just and fair socio-ethical and legal order, Islam adopted the policy of recognition or rejection (Tabari, 1988; Mubarakpuri, 1995; Salam, 992). Through divine revelation, Almighty Allah rejected all those customary practices which were against the objectives of Shari'ah (Islamic legal system) and recognized those which were in accordance with the objectives of Shari'ah (Rida, 1987; Qardawi, 1990; Ashur, 2000). As Hamidullah (1998) pointed out that through revelation, Almighty Allah warned the Arabs regarding their wrong perceptions and corrupt practices against women and made them bound to leave corrupt customary laws and to follow the Qur'an and the Sunnah (pbuh).

The issue of gender disparity was also resolved through revelations on priority basis and declared a woman equal to a man from all aspects. At present, the UNO and human rights activists call for the equality of women on the basis of humanity. This right, however, has been granted by Almighty Allah fourteen hundred years ago by declaring in chapter 4, verse no 1, as: "O mankind! Be fear of your Lord who created you from single soul...”. Thus, Islam established the doctrine of equality between men and women as being them human (Al-Razi, 1965; Al-Tabari, 1988; Zaydan, 1997; Al-Ashqar, 1992).

Likewise, the corrupt practice of the killing of the baby girls was rejected by Allah Almighty. It is mentioned in the Qur'an (Chapter 81, verse 31): "And when the baby-girl who was buried alive would be questioned: For what sin she was slain?” Here, Allah Almighty described the right to life with reference to the women which is a great reward for women.

The reason is that the trait of self-respect is placed by Allah Almighty Himself in the nature of all human beings, men and women by declaring human being honored and superior to all other creatures in this universe. It is stated in the Qur'an: “And indeed We have honored the children of Adam and We have carried them on land and sea and... and have preferred them above many of those whom We have created with a marked preferment" (Chapter 17, verse 70).

To ensure social equality, Allah Almighty repeatedly declared men and women equally, as protectors, and as brothers and sisters of each other. It is stated in the Qur'an (Chapter 9, verse 71): "The Believers, men and women, are protectors to each other...". Moreover, Allah Almighty has declared that both men and women are equally responsible and accountable before Him for their acts good or bad in their individual capacities. The Qur'an states: "So their Lord accepted their supplication that never will I allow to be lost the work of any of you, be the man or a woman...." (Chapter 3, verse 195).

In Islam, the family system is started by way of nikah/marriage (Al-Ghazali, 1985; Ibn Rushd, 1985; Zaydan, 1997; Zahra, 1988), and to reduce disparity between husband and wife and to strengthen the family system, Allah Almighty revealed the verse 228 in chapter 2 (Sura al-Baqarah) as: "And they (women) have the same rights as of men over them in kindness (humanity basis).” To ensure the equal rights of a woman as a wife, Allah Almighty declares: "They are for you as your dress and you are their dress" (Chapter 2, verse 187).

Like the Qur'an, the Prophet Muhammad (pbuh), also showed His (pbuh) great concern regarding gender equality and established a such environment in which all the Muslims, men and women were quite free, and were granted equal rights in getting education, equal access to health and survival, equal economic opportunities, and equal participation in all political activities to exercise their 
socio-economic, cultural and religious rights.

To promote respect of the women in society, the Holy Prophet (pbuh) said: "The Best among the believers, who is the best toward woman" (Imam Hanbal, 1989). To protect the women at home, the Prophet (pbuh) said: "The best of you who is the best for his wife, and I am the best of you for my wives" (Al-Tirmadhi, 1980). The Holy prophet (pbuh) warned the Muslims to be careful regarding the rights of the women by declaring: "To be afraid of Allah regarding your wives. For them you are like trustees” (Imam Bukhari, 1980, V.9, 110).

The Holy Prophet (pbuh) always showed great respect towards His (pbuh) wives and cared for their self respect. Once a Persian invited the Prophet (pbuh) at lunch while Hadrat Ayesha (RA) was there. The Holy Prophet aimed at her and asked the persian: "Is she too invited? He replied: "no". Then Holy Prophet (pbuh) said: So, I will not come.” The person went back and came again again but the Holy Prophet (pbuh) did not agree to have lunch with him without accompanying Hadrat Ayesha (RA) and finally, that person invited Hadrat Ayesha too. Then Holy Prophet (pbuh) accepted his invitation" (Imam Bukhari, 1965; Al-Tirmidhi, 1980).

Talking about "Global Gender Gap Index" targeted areas, the first one is to examine gender equality in getting knowledge between men and men, so this area is being analyzed in the light of the Quran and Sunnah (pbuh). It is not out of mention here that the majority of the legal texts of the Qur'an and the Sunnah (pbuh) are in general and common words like "O human being" and "O believers" and these and similar words include both men and women and are applicable to all (Khallaf, 1993;Razi, 2001).

The issue of getting the education on equal basis has been addressed by Allah Almighty in the first ever revealed verse which focused on the importance of getting education and human beings have been ordered by Almighty Allah to learn how to read and write (Chapter 96, verses 1-5).

Another Qur'anic verse (chapter 58, verse 11) states: "Allah will raise up to ranks those of you who believe and who have been granted knowledge and Allah is well acquainted with all you do". The Holy Prophet said:" Who travels for learning \& knowledge, God makes easy, his/her way to paradise" (Al-Tirmidhi, 1980). In this hadith the word "who" includes both man and woman. In the same manners, a hadith is reported from Anus bin Malik that the Holy Prophet advised regarding "getting knowledge, whether one has to go to China, as getting knowledge is an obligation”(Ibn Bar,1983).

Above all, to provide more chances of getting the education to women, the Holy Prophet (pbuh) had to arrange separate sittings with the women to teach them properly without interference of the men, though women had to attend the joint meetings with the men as well (Al-Bukhari, 1980; Siddique, 1998; Mubarakpuri, 1995).

This discussion thus, makes it clear that Islam recognizes the right of getting knowledge as one of the fundamental rights of the women like men and motivates its believers to provide equal opportunity to access to knowledge to both, men and women.

The second targeted field of "The Global Gender Gap Index 2002" is to examine the level of equality between men and women in access to health and survival (http://www3.weforum.org/docs). Islam addresses this issue on an equal basis and declared the health of women is as important as of 
men. The importance of the health of a woman can be judged by the fact that Almighty Allah has prohibited, every husband from becoming a cause of mental torture towards his wife (chapter 2, verse 231; 233). The Holy Prophet himself (pbuh) had to care for the health of women even for non-believer women ((Al-Bukhari, 1980; Siddique, 1998; Muslim, 1990).

Islam declares cohabitation with wife and producing of children as one of the primary objectives of nikah and a matter of reward (Abu Dawud, 1968, V.5, no 705), yet to preserve the health of the woman, contraceptive methods can be adopted to control producing more children (Al-Bukhari, 1980; Ghazali, 1980; Razi, 2013). Imam Ghazali has discussed in details the permissibility of the contraceptive methods for the protection of the health of women (Ghazali, 1980).

Talking about services of the women in the health sector, Islam has provided equal opportunities to both men and women. Hadrat Khaula bint Qays, a woman companion had reported that during the period of the Prophet (pbuh), we (women) had a get together in the mosque to discuss our matters with our friends, while some skilled women had to treat eye patients (Ibn Sa'd, 1980; Al-Shaqqa, 200o). Ume A'la, a female companion had reported that Uthman bin Maz'un became sick during his stay at her home, and she had to attend him until his death". Likewise, the Holy Prophet (pbuh) took women to Jihad to assist and to treat wounded soldiers and they were given shares from Mal-e-Ghanimat (Imam Bukhari, 1980,V. 5, no 197).

So far as concerned the third targeted area, the equality between men and women in access to political opportunities, history has recorded that during the time of the Holy Prophet (pbuh) and his companions, the Muslim women had equal access to all sociopolitical discussions, sessions and meetings and activities (Abu-Shaqqah, 2002; Bukhari, 1980; Muslim, 1965).

Umme Sharik, was a very rich and generous lady. She declared her house a guest house. Many companions had to stay at her home. She had to attend her guests and the Holy Prophet (pbuh) had to admire her services ((Abu-Shaqqah, 2002; Bukhari, 1980; Muslim, 1965). The wife of Hadrat Abu Bakr was also a social lady and companions had to come her home for discussion and consultation (AbuShaqqah, 2002; Bukhari, 1980; Muslim, 1965).

An unmarried girl, Umme Kalsum bint A 'qbah accepted Islam and migrated to Madinah, the Holy Prophet (pbuh) welcomed her and refused to take her even on the demand of her family (AbuShaqqah, 2002; Bukhari, 1980; Muslim, 1965).

After death of the Holy Prophet (pbuh), Hadrat Ayesha (RA) did not discontinue her communication with Arab leaders and leaders of different tribes had to write letters to her, had to send her gifts and Hadrat Ayesha had to reply them and had to accept their gifts (Abu-Shaqqah, 2002; Bukhari, 1980; Muslim, 1965).

Talking about the last area regarding gender equality in the field of economic opportunities, business and trade (http://www3.weforum.org/docs), Muslim women had equal access to all economic activities and markets without any restriction (Abu-Shaqqah, 2002; Bukhari, 1980; Muslim, 1965). It is reported that whenever a trade delegation had to enter Madinah, women had to rush towards that and gathered around it to know the cost and to purchase goods, the Holy Prophet (pbuh) was among them, but He (pbuh) never prohibit women from participation in the trade activities (Abu-Shaqqah, 2002). 
Another Hadith is that Umme Mubashir Ansariyah was a farmer and had to cultivate her land and Holy Prophet (pbuh) appreciated her (Bukhari, 1980; Muslim, 1965). Hadrat Maimunah bint Harith, wife of Holy Prophet (pbuh) was the owner of a maid slave. Hadrat Maimunah set free her maid without informing the Holy Prophet (pbuh), rather told him (pbuh) after a few days and the holy Prophet (pbuh) did not mind it" (Bukhari, 1980; Muslim, 1965).

It was a result of such training that the companions could not dare to prevent their women from exercising their fore granted rights. For instance, Hadrat Umar personally, was not in favor of arrival of women in mosques regularly. However, he could not prohibit her wife from doing so due to the order of the Holy Prophet (pbuh): "Do not prohibit women, slaves of Allah from coming to mosques (Bukhari, 1980; Muslim, 1965). The traditional Muslim jurists also dealt the issue of gender equality in the light of the context of their time (Al-Asqalani, 1978; Al-Ghazali, 1980; Ibn Qayyim, 1968; Fazlur Rahman, 1990).

In this way, through divine revelation and wise policies of the Prophet (pbuh), the issue of gender disparity become vanished among the Muslims during the golden period of Islam. The Holy Prophet (pbuh) did not forbid the Muslim women from participation in the social and political gatherings and from earning. Rather, adopted a lenient and flexible policy in favor of the women. All that led the women to participate actively in all political, social and religious gatherings. As Abu Shaqqah (2002) pointed out that although statistics show women as half of the total population, yet they are more effective than men in their responsibilities and affects upon their families".

\subsection{Gender Disparity In Pakistan: A Critical Anaylsis}

Pakistan is an Islamic Republic which means that the whole structure of the society will be developed in the light of the Qur'an and Sunnah (pbuh) (The constitution of Pakistan, 1937).

It is, however, a matter of great concern that currently, Pakistan is suffering from many acute socioeconomic and political issues and a thorough study of these problems, explores that many of the issues are because of the ignorance of the teaching of the Qur'an and Sunnah (pbuh). For, instance, the illiteracy rate is very high in Pakistan and almost $50 \%$ of the population is ignorant (https://www.google.com/search /education; https://www.ungm.org), and this is because of the ignorance of the Qur'anic verses and Sunnah (pbuh) regarding the importance of getting knowledge (Chapter 3, verse 105; Chapter 96, verses 1-5).

So, is the case of gender disparity, Pakistan is an Islamic state with $96.4 \%$ Muslims, yet the issue of gender disparity is rising every year ((https://www.google.com/search /education; https://www.ungm.org). Women are constituent 49\% in Pakistan yet have a very little participation in the socio-economic development of the country. The issue of gender disparity also causing to create many other issues for a Pakistani woman like illiteracy, poverty, domestic violence, gang rape, honor killings, bonded labor, deprived of her right of inheritance and marriage without her consent.

Since, 2006, Pakistan is scored among the lowest ranked countries in "Gender Gap Index" following by Yemen while India has a better rank than Pakistan. Singh (1998) has explained the condition of Muslim women in the subcontinent as: "that Muslim women of Sub-Continent were never thought to be equal to men in any way. Since long time they were asked to live within the four walls of their houses. They were rarely given a chance to expose and to show that they too had a brain or thoughts of their own”. 
In 2006, the first ever "Global Gender Gap” reported Pakistan as ranked 112 out of 146 countries, while in 2020, Pakistan scored 3rd worst rank 151 out of 153 countries after Iraq and Yemen (The World Economic Forum, Gender Gap Index Reports, 2006 and 2020), and this proves that the issue of gender disparity could not be reduced in Pakistan.

The following table below presents a comparative analysis of Gender Gap in four targeted areas from bottom line of Gender Gap Index Reports 2006 and 2020 respectively (The World Economic Forum, Gender Gap Index Reports, 2006 and 2020).

Table 1.1 Gender Gap in Four Targeted Areas

\begin{tabular}{|l|l|l|l|l|l|}
\hline SN & Year & $\begin{array}{l}\text { Gap in access to } \\
\text { education(from } \\
\text { bottom) }\end{array}$ & $\begin{array}{l}\text { Gap in access } \\
\text { to health }\end{array}$ & $\begin{array}{l}\text { Gap in } \\
\text { Economic } \\
\text { participation }\end{array}$ & $\begin{array}{l}\text { Political } \\
\text { opportunities }\end{array}$ \\
\hline 1 & 2006 & 110 & 112 & 112 & 37 \\
\hline 2 & 2020 & 143 & 149 & 150 & 93 \\
\hline
\end{tabular}

This table shows the issue of gender disparity is getting worsening every year. Talking about the issue of gender disparity in Pakistan, with reference to the four targets set by the (Global Gender Gap Index, 2002), the $1^{\text {st }}$ target is the equal opportunity in access to education, the situation is being fermented like in 2006 Pakistan scored 110 rank among 145 states, but in 2020, it scored 143 a bottom rank among 151 countries of the world (The World Economic Forum, Gender Gap Index Reports, 2006 and 2020). The statistics show that overall $75 \%$ of Pakistani women never attended school at all. In rural areas, about 98.8\% women are deprived of education. Among girls between 5 to 10 years of their age about 32\% could not attend schools.Only 10\% of women have access to post-secondary level of education (http://www.google.com/gender+inequality+in+education+in+pakistan).

With respect to the $2^{\text {nd }}$ target, equality between men and women in economic participation, in 2006,Pakistan scored 112 which has fallen to 150 in 2020. The recent data shows that Pakistani women are participant of only $22.8 \%$ of the labour force while the world average is $51.90 \%$, based on the data from 182 states (www.theglobaleconomy.com/Pakistan).

Moreover, professional women are suffering from the issue of harassment and are lagging behind due to gender disparity (http://www.google.com/search /harassment at workplace/Pakistan). Siddiquah and Pell (2014) pointed out that at the universities of Pakistan, only few Professional women succeed to enjoy administrative positions at universities. In the business sector, only $1 \%$ women are involved in direct business and finance (https://www.dawn.com/news/1471148/pakistan). Here, it is crucial to understand that "Pakistan's inclusive growth targets" demands that participation of women in the economic field demands arise from current 26\% to about 45\% (World Economic Forum, 2020).

In the field of health and survival, the $3^{\text {rd }}$ target, in 2006, Pakistan scored 112 rank which has fallen to 149 in 2020 (Global Gender Gap Index Reports 2006 and 2020). The "UN Sustainable Development Goal Report (2019), presented Pakistan among the top four countries, where about 4.9 million women between 18 to 49 years of age are deprived of health facility. More than 52.5\% women of rural areas and $39.3 \%$ of urban areas do not have access to health facilities on time and can't approach doctor/medicine with on their own decisions (https://www.ungm.org/Public/report/pdf). The gap regarding health services and survival is about $94.6 \%$, which leads that only $6 \%$ of women 
have access to health care as men ((Global Gender Gap Index Report, 2020).

Likewise, equality between men and women in the field of political opportunities, the $4^{\text {th }}$ target, Pakistan scored 37 rank in 20026 which has fallen to 93 in 2020 ((Global Gender Gap Index Reports 2006 and 2020).All this leads that the governments of Pakistan never showed their interest in the issues of the women.

Looking into the causes behind the development of the issue of gender disparity in Pakistan, apart from government negligence cultural rigidity and lack of scientific understanding of the Qur'an and Sunnah (pbuh) are major hurdles in the way of gender equality in Pakistan. The cultural context of Pakistan, is primarily based on the ancient customary practices more than religious norms. Longestablished traditional practices are deeply rooted in the society and can be traced in centuries old Hind culture (Lodhi, 2011). As Advani (2008) pointed out that "India and Pakistan is a place of many ethnic groups and nations and each of them has its own culture which has made the culture of Pakistan complex and rigid".

Although Muslims ruled over the subcontinent for more than one thousand years, yet could not reduce the cultural rigidity rather adopted it and gave it religious colour (Raza, 1994). The issue of gender disparity is one those issues which the Muslims adopted by following strict and rigid local customary practices backed in Hindu culture and is still continuing ( Raza, 1994; Chiragh, 1996; Lodhi, 2011). The existing cultural rigidity of that time, also influenced the Muslim intellects of Indo-Pak and led them to interpret the verses of the Qur'an and Sunnah (pbuh) regarding the issues of women in very strict manners. Most of the interpreters and the translators of the Qur'an and Sunnah (pbuh) adopted very inflexible and stagnant modes (Rida, 1998; Afghani, 1965).

For instance, word-by-word literal translation of the verses of the Qur'an in Urdu language translates the word the word "قَوَامون" (Chapter 4, verse 34) in the meaning of "Ruler" and a strict word "Hakim" has been enforced upon this word by all the Urdu translators, which has created so many difficulties for the Muslim women of the sub-continent (Rida, 1998; Razi, 2014). As Razi (2014) pointed out that by assigning such an inappropriate and strict meaning to the relevant verses of the Qur'an and by ignoring the Sunnah of the Prophet (pbuh) and changed social context, the translators, thus, have a great role in establishing gender disparity among the Muslims of the sub-continent generally, and in Pakistan particularly”. This word “ قوَامون” however, is a general word and is used in the meanings of caretaker, guardian, keeper, and custodian (Ahmed Ali, 2000; BaalBaki, 2001).

Further, the generous distribution of the authority of issuing fatw $\bar{\alpha}$ in Pakistan has created so many problems for the people regarding the true nature and spirit of Islamic law (Razi, 2014). To restrict the freedom of women, many of the muftis of Pakistan are issuing strict fatawa which have a constructive role to rise up gender disparity. These fatawa, however, are issuing without logical and scientific understanding of the Qur'an and the Sunnah (pbuh) and the changed context (Ibn al-Qayyim, 1998). For instance, in April 2012, a fatwa was issued in Kohistan against the women of NGO's: “that they would be compelled to get married to the local men of Kohistan if they would dare to enter there. Likewise, in May 2012, in a mosque of Noshki, Balochistan, a fatwa was issued: "that any women using a cell phone will have acid thrown on her face” (The Express Tribune, April 2012; May 2012).

This situation does not confine just to the muftis of private madaris/ religious schools rather 
muftis of the Constitutional institutions like "Council of Islamic Ideology", 1 have very strict behavior towards the issues of women. For example, in 2013, the then chairman of Council of Islamic Ideology rejected the 'Women protection Act' and declared it as un-Islamic (News paper Dawn, September 2013).

Likewise, in 2014, CII in its meeting held "Muslim Family Ordinance 1961" as UnIslamic and a subject to amendment. Moreover, talking about the Child Marriage Restraint Act, which prescribes the minimum age of marriage 18 years, the Chairman of the Council declared that "the laws which determine a minimum age for marriage is not Islamic that the parliament should amend these laws to bring them in accordance with Islamic principles" (Dawn, 22 May, 2014).

However, since last decade, few legislations have been made to protect the women from disparity, violence, and harassment both at home and at work place. For example, "Harassment of Working Women at Work Place Act 2010", “Act against Domestic Violence”, and "Child marriage restraint Act", yet laws become ineffective because of lack of concern of law enforcing agencies which do not ensure the implementation of the laws and leave the issues of the women at the discretion of the male family members by considering them personal or family issues.

Later on, to improve the situation and to reduce gender disparity in Pakistan, the government has established a "Pakistan's development road map "Vision 2025" as a determined goal to rise in "female labor force participation (FLFP)" from its present level of $22 \%$ to $45 \% \quad 2025$ (https://openknowledge.worldbank.org/handle/10986/30197).

\section{Conclusions And Recommendations}

This study thus, concludes that Islam recognizes women equal in status and honor to men and that the dogma of gender discrimination is against the Qur'an and Sunnah (pbuh). The study found no evidence which shows that the Holy Prophet (pbuh) and his companions dealt with issues of the women by way of discrimination on the basis of their gender. The study also found the issue of discrimination against women is prohibited in Islam.

The study, however, found that cultural rigidity, illiteracy, lack of knowledge of social and legal science among muftis, lack of scientific understanding of the Qur'an and Sunnah (pbuh), are most critical factors in establishing gender disparity in the society and a great cause behind the failure of the efforts of the government for women empowerment and closing gender gap.

This research, thus, recommends spreading awareness among the people as the knowledge can shape the social, political and religious context.

This study further, recommends to reform the overall system of education and relevant verses of the Qur'an and ahadith (pbuh), and practices of the companions should be added in the scheme of study at all the educational institutions of Pakistan.

1 The Council of Islamic Idealogy has been established under Article 228 of the Constitution of Pakistan 1973. The functions of the Council have been mentioned in Article 230. The functions of the Islamic Council shall be- (a) to make recommendations to 3 [Majlis-e-Shoora (Parliament)] and the Provincial Assemblies as to the ways and means of enabling and encouraging the Muslims of Pakistan to order their lives individually and collectively in all respects in accordance with the principles and concepts of Islam as enunciated in the Holy Quran and Sunnah; (b) to advise a House, a Provincial Assembly, the President or a Governor on any question referred to the Council as to whether proposed law is or is not repugnant to the Injunctions of Islam; (c) to make recommendations as to the measures for bringing existing laws into conformity with the Injunctions of Islam into effect; and (d) to compile in a suitable form, for the guidance of 1 [Majlise-Shoora (Parliament)] and the Provincial Assemblies, such Injunctions of Islam as can be given legislative effect. See, Counsitution of Pakistan 1973, Articles 228-230. As modified upto the 31st May, 2018 by the National Assembly of Pakistan. 
At home, the father is guardian so, is responsible to ensure the education of his daughter and let her to contribute in the socioeconomic development of the country.

At the state level, the government is responsible to enact effective laws to ensure protection of the rights of women. The law enforcing agencies must ensure the implementation of the legislation enacted to protect the women from violence, harassment and discrimination.

This study, also recommends restricting the authority of issuing fatawa in the country and that only highly qualified person, experts in both fields like social sciences and Qur'anic sciences, should be awarded a certificate to issue fatawa (Anduh and Rida, 1990).

\section{References}

Al-Qur'an al-Karim

Chiragh, Muhammad Ali. (1996). Tarikh-e-Pakistan. Lahore: Sang-e-Mil Publications.

Raza, Khan Muhammad. (1994). Tarikh musalmanan-e-Aalam. Lahore: Ilmi Kitab Khana.

Women, Gender, Sexuality Studies. UNIVERSITY OF MASSACHUSETTS AMHERST LIBRARIES AMHERST, MA.

Morgan, Robin. 1996. "Introduction - Planetary Feminism: The Politics of the 21st Century.” Pp. 1-37 in Sisterhood is Global: The International Women's Movement Anthology, edited by Morgan. New York: The Feminist Press at CUNY.

Greenberg, J. 2002. "Definitional Dilemmas: Male or Female? Black or White? The Law's Failure, to Recognize Intersexuals and Multiracials”. Pp.102-126 Madison: University of Wisconsin Press.

Connell, R.W. 1987. Gender and Power: Society, the Person, and Sexual Politics. Palo Alto, CA: Stanford University Press.

Gerstel, N. 2003. Family in The Blackwell Dictionary of Modern Social Thought. Blackwell: Publishing, Ltd.

Jepperson, R. 1991. Institutions, Institutional Effects, and Institutionalism.Pp. 143-163. Chicago: University of Chicago Press.

Kirk, G., and M., Okazawa-Rey. 2004. Violence Against Women in Women's Lives: Multicultural Perspectives. New York: McGraw-Hill.

Duggan, Lisa. 2003. The Twilight of Equality? Neoliberalism, Cultural Politics, and the Attack on Democracy. Boston: Beacon Press.

Enloe, Cynthia. 2008. “The Globetrotting Sneaker.” Dubuque, Iowa: Kendall Hunt Pub Co.

Debois, E., and L., Dumenil. 2005. Through Women's Eyes: An American History with Documents. St. Martin Press.

Thomas, R. M. 1998. Oriental Theories of Human Development, ed. New York: Peterlan.349.

DAVIE,GRACE. 2015. Poverty Knowledge in South Africa, A Social History of Human Science 1855-2005. Cambridge: University Press.

Ludwig, Gumplowicz. 2011. The Out Lines of Society, trans. F.W. Moore. Cambridge: University Press. 177-178.

Buenfil, R.N. 2011. Discussing Democracy in the Area of Education. RIED-

IJED. Interamerican Journal of Education for Democracy, 1 (4), 29- 51.

Winch, Peter. 2003. THE IDEA OF A SOCIAL SCIENCE and its Relation to Philosophy. Taylor and Francis: e-Library.

UN, Women Office. 2003. Progress of the World's Women 2002: Volume 2: Gender Equality and the Millennium Development Goals”. @ https://www.unwomen.org/en/ progress-of-the-world-swomen-2002-volume-2. 
https://www.un.org/en/sections/issues-depth/gender-equality.

https://www.unwomen.org/en/digital-library/multimedia/2019/12/infographic-human-rights.Last accessed on 5-08-2020.

United Nations, Report. July 2001. Gender Mainstreaming. New York: NY 10017USA. @ https://www.un.org/womenwatch/osagi/pdf/e65237.pdf. Last accessed on 12-10-2020.

UNO, Women Office. 2000. Progress of the World's Women 2000. @ https://www.un.org/. Last accessed on 12-10-2020

Salam, Izz bin Abd al-. 1992. Qawa'id al-Aḥkam fi Masaleh al-Anam. Ed. 'Abdul Ghani. Damishq: Dar al-Taba' li al-Nashr wa al-Tawzi'.

Rida, Rashid. 1985. Tafsir al-Manar. Misr: Beirut: Dar Sadir.

Qardawi, 1992. Yusuf al-. Al-Ijtihad fi al-Shari'ah al Islamiyahah. Kuwait: Dar al-Qalam.

Aashur, Tahir bin. 200o. Maqașid al-Shari'ah al-Islamiyyah. Ed. Muhammad Tahir. Beirut: Dar alBașair lil Intaj al- 'Ilmi.

Raisuni, Ahmad al. 1995. Nazriyyah al-Maqașid 'inda al-Shațibi. Beirut: Ma had al-'Ilmili al-Fikr alIslami.

Shachar, Ayelet. 2001. Multicultural Jurisdictions: Cultural Differences and Women's Rights. New York: Peterlan.

Gutwie, W. KC. F.B.A. 1962. A History of Greek Philosophy. Cambridge: Cambridge University Press.

Betoncourt, H. \& Lopez, S.R. 1993. The Study of Culture Ethnicity and Race in American Psychology. USA: American Psychologist.

Ibn Hashsham, Abu Muhammad 'Abdul Malik. 1990. Sirah al-Nabawiyyah. Cairo: Matba’ah Hijazi.

Zaydan, Abdul Karim. 1997. Al-Mufassil fi Ahkam al-Mar`at wa Bait al-Muslima. Bairut: P.O Box, 117460.

Ashqar, Umar Suleman, al-. 1992. Ahkam al-Ziwaj fi Daw al-Kitab wa al-Sunnah. Bairut: Dar Nafais li al-Nashr.

Al-Ghazali, Muhammad bin Muhammad. 1985. Ihyaa 'Ulum Id-Din. Lahore: Islamic Publications. 1990. Al-Mustasfa`Egypt: Al-Matba`al-Amiriyah.

Ibn Rushd, Abu al-Walid. 1989. Bidayatul-Mujtahid wa Nihayahtul-Muqtasid. Lahore: Faran Academy. Imam Hanbal, Ahmad bin Suleman, al-Shaibani. 1989. Al-Musnad.Cairo: Hajr li al-Taba 'wa al-Nashr. Abū 'Abd Allōh. I' lōm al-Mawaqqi īn 'an Rabb al- 'Ālamīn ed., 4 vol. Mișr: Matba ah al-Sa '̄̄dah, 1955. Ibn al-Qayyam, Muḥammad bin Abi Bakr, al-Jawzi. 1999. A ’lam al-Mawqaeen an Rabb al-Aalamin. Ed. Muhayy al-Din. Cairo: Dar al-Kutub al-Islamiah.

Fazlur, Rahman. 1984. Islamic Methodology in History .Islamabad: Islamic Research Institute.

Imam Muslim, Muslim bin Hajjaj bin Muslim Qushyri. 1989. Sahih al-Muslim. Beirut: Taba h Dar alSha $b$.

Al-Tirmidhi. 19986. Sunan -al- Tirmidhi., Kitab Al-Ilm, Bab Fadl Al-Ilm, 3:34

Ibn, Abdul Bar. 1983. Jama` Bayan al-Ilm wa Fadlahu . Cairo: Dar al-Kutub al-Islamiah.

Imam Daud, Sulayman ibn al-Ashath. 1969. Sunan Abi Dawud. Cairo: Dar al-Hadith.

Razi, Naseem. 2013. Family Planning as National Policy in Pakistan: An Analysis from the Perspective of Shari'ah. Pakistan Journal of Islamic Research. V.12, Pp. 1-14.Multan: BZU.

.June 2014. MODES OF THE QUR'ANIC TRANSLATION: An Analysis of Urdu Literal Translation in the light of the Contextual Mode. Hamdard Islamicus. Vol. XXXVII, No.2, pp.53-84.

December 2014. Fatwa as a Non-State Legal System: A Critical Analysis from the Perspective of Pakistani Society. Journal of Islamic Studies and Culture. Vol. 2, No. 4, pp. 7-18. ISSN: 2333-5904 (Print), 2333-5912 (Online). Published by American Research Institute for Policy Development DOI: 10.15640/jisc.v2n4a2 URL: @ http://dx.doi.org/10.15640/jisc.v2n4a2.

Ibn Sa`d, 1980. Tabqat al-Kubra. Bairut: Dar al-Kutub al-Ilmiyah. 
Imam Bukhari, Muhammad bin Ismail. 1990. Sahih al-Bukhari. Cairo: Majlis al-Sha’b.

Abu-Shaqqah, Abdull Halim Muhammad. 2002. Tahrir al-Mar'ah fi 'Asr al-Risalah. Cairo: Majlis alSha'b.

Al-Asqalani, Ibn-e-Hajr. 1990. Fathul Bari Sharah Sahih al-Bukhari . Cairo: Mustafa` al-Halbi.

Rafiq, Butt, M. 2009. Commentary on the Constitution of Pakistan 1973. Lahore: Mansoor Book House.

Singh, N. K. 1998. Social Justice \& Human Rights in Islam. New Delhi: Gyan Publishing House.

https://www.dawn.com/news/1471148/pakistan.

https://www.google.com/search /gender+inequality+in+education+in+pakistan. Last visited on 3-122020.

https://www.theglobaleconomy.com/Pakistan/Female_labor_force_participation/. Last visited on 812-2020.

Shauka, S., Siddiquah, A., \& Pell, W.A . 2014. Gender discrimination in higher education in Pakistan: A survey of university faculty. Eurasian Journal of Educational Research.56, Pp. 109-126. @ http://dx.doi.org/

Dawn, News published. 22-03-2020. @ https://www.dawn.com/news/

UN, Sustainable Development Goals. Report 2019. @ https://www.ungm.org/Public/report/pdf. Accessed on 6-09-2020.

World Economic Forum (WEF), Global Gender Gap Index Report 2020.

World Bank. 2014. @ https://openknowledge.worldbank.org/handle/10986/30197 License: CC BY 3.0 IGO.

https://openknowledge.worldbank.org/handle/10986/30197

Sugata, Bose and Ayesha Jalal. 2004. MODERN SOUTH ASIA: History, Culture, Political Economy. New York: Routledge 29 West 35th Street.

Hartup, Willard. 2002. Social Relations and their Developmental Significance. USA: American Psychologist.

Michael, Lewis. 1990. Social Knowledge and Social Development. Merrill Palmer Quarterly. Pp. 93-101.

Lodhi, Maleeha. 2011. Pakistan beyond the Crisis State, Edt. Oxford: Oxford University Press.

Advani, L.K. 2008. My Country My Life. New Delhi: Ansari Road.

BaalBaki, Rohi, al-. 2000. Al-Mawrid.beirut: Dar Sadir.

Ali, Ahmed. 1987. Al-Qur'an: A Contemporary Translation. Delhi: Oxford University Press.

https://www.expresstribune.com/news/. Last accessed on 12-10-2020.

https://www.dawn.com/news/1044879. 